\title{
PENENTUAN HARGA DAN PEMBAYARAN TEMPO PIUTANG PELANGGANDALAM PERSPEKTIF ETIKA BISNIS SYARIAH (STUDI KASUSDI LINGKUNGAN INDUSTRI KULIT MAGETAN)
}

\author{
Muhammad Zaahidul Alim \& Warsidi \\ Email: zaahid11@gmail.com
}

\begin{abstract}
Abstrak
Penentuan Harga Dan Pembayaran Tempo Piutang Pelanggan Dalam Perspektif Etika Bisnis Syariah Studi Kasus Lingkungan Industri Kulit Di Magetan.Bisnis tidak bisa lepas dari akad transaksi jual beli. Bisnis merupakan serangkaianperistiwa yang melibatkan penjual dan pembeli, terkait dalam penentuan harga dan sistem pembayaran yangkompetitif, menjadikan lingkungan bisnis berubah sehingga harus lebih memperhatikan etika dan norma untuk dapat tercapainya tujuan. Etika bisnis syariah merupakan suatu norma yang bersumber dari Al-Qur'an dan Haditsyang dijadikan pedoman untuk bertindak, bersikap, bertingkah laku sertamembedakan antara mana yang baik dan mana yang buruk dalam melakukanaktivitas bisnis. Sekarang ini banyak para pebisnis yang bersaing dari segi harga barang dan sistem pembayaran untuk meningkatkan penjualannya. Meskipundalam kenyataannya hal ini dapat merugikan dan beresiko bagi perusahaan. Oleh karena itu, perusahaandituntut untuk cepat tanggap dalam menghadapi persaingan dengan memperbaikisistemnya. Tujuan dari penelitian ini adalah untuk menjelaskan pelaksanaan etikabisnis Islami dalam penentuan harga dan pembayaran tempo di lingkungan industri kulit magetan. Metode yang digunakan adalah penelitian kualitatif deskriptif. Tehnik pengumpulan data yang digunakan yaitu observasi, wawancara dan dokumentasi. Hasil penelitian ini menunjukkan bagaimana penentuan harga dan sistem pembayaran tempo piutang pelanggan di lingkungan industri kulit magetan.
\end{abstract}

Kata Kunci: Harga, Pembayaran, Tempo, Piutang.

\section{PENDAHULUAN}

Etika Bisnis Syariah telah mensyariatkan etika yang rapi dalam aktivitas bisnis. Etika bisnis akan membuat masing-masing pihak merasa nyaman dan tenang, bukan saling mencurigai. Etika bisnis dalam Islam telah dituangkan dalam hukum bisnis Islam yang biasa disebut dengan muamalah. Aktivitas ekonomi yang bertujuan untuk memenuhi kebutuhan hidup manusia mempunyai aturan-aturan tertentu, sebut saja aturan dalam hal jual beli (ba'iy), pinjam meminjam (ariyah), utang mengutang, berinvestasi (mudharabah), kerjasama bisnis (musyarakah), menggunakan jaminan (rahn), pengalihan utang (hiwalah) dan masih banyak jenis transaksi lainnya. ${ }^{1}$

\footnotetext{
${ }^{1}$ Eko Zulkifli, Etika Bisnis Syariah, dalamhttp://kumpulanmakalahekoszulkiflilih awa.blogspot.com/2016/10/makalah-etikabisnis-syariah.html (18 Oktober 2016)
} 
Betapa indahnya cara Rasulullah Saw. menjajakan barang dagangannya dengan memilah jenis barang berdasarkan kualitas dengan menetapkan harga sesuai dengan kualitas barang. Tidak ada kualitas dan harga barang yang ditutupi Rasulullah Saw. Semuanya berdasarkan harga yang wajar sesuai dengan kualitas barang yang biasa kita sebut dengan product liability. ${ }^{2}$

Namun, lebih dari itu, hubungan bisnis dalam Islam adalah manifestasi dari ibadah kepada Allah Swt. Sudah menjadi adat umum di masyarakat, jika tidak bisa menipu atau atau bermain "kotor" akan tersingkir dari dunia bisnis. Dengan kata lain, seorang pebisnis tidak bisa "lepas" dari prilaku kotor, tipu muslihat dan semacamnya, jika jujur maka akan terbujur. Paradigma seperti ini tampaknya sudah menjadi "kesepakatan" masyarakat kita. Memang harus diakui karena bisnis berkaitan dengan uang maka peluang dan godaan untuk melakukan penipuan dan kebohongan sangat terbuka lebar.

Berpijak dari masalah tersebut di atas yang mendorong penyusun mengadakan penelitian di lingkungan industri kulit magetan dengan mengambil judul "Penentuan Harga Dan Pembayaran Tempo Piutang Pelanggan Dalam Perspektif Etika Bisnis Syariah (Studi Kasus Lingkungan Industri Kulit Di Magetan)".

Jenis penelitian yang gunakan penulis dalam penelitian ini adalah jenis penelitian dengan pendekatan kualitatif deskriptif. Menurut M. Nasir pendekatan

${ }^{2} \mathrm{Ibid},$. kualitatif deskriptif adalah suatu metode dalam meneliti sekelompok manusia, suatu objek bahkan suatu sistem persepsi atau kelas peristiwa pada masa sekarang bertujuan untuk menggambarkan secara sistematis, factual dan akurat mengenai faktafakta, sifatsifat antara fenomenayang diselidiki. $^{3}$

$\begin{array}{cc}\text { Menurut } & \text { Moleong } \\ \text { pendekatan kualitatif } & \text { deskriptif }\end{array}$ adalah menetapkan objek apa adanya sesuai dengan bentuk aslinya, sehingga data yang sesungguhnya dapat diperoleh.Dari dua sudut pandang M. Nasir dan Moleong cukup memberikankontribusi pemikiran kepada peneliti dalam menghasilkan data yang akurat, baik secara tertulis maupun secara lisan dari respoden dan informan. Sebab pendekatan ini menggambarkan secara apa adanya dengan lugas dan rinci serta berusaha untuk mengungkapkan data tentang "Penentuan Harga Dan Pembayaran Tempo Piutang Pelanggan Dalam Perspektif Etika Bisnis Syariah (Studi Kasus Lingkungan Industri Kulit Di Magetan)". ${ }^{4}$

M. Nasir menambahkan bahwa penelitian menggunakan pendekatan kualitatif deskriptif mempunyai beberapa ciri sebagai berikut:

1. Natural Setting yaitu, data dikumpulkan secara langsung dari lingkungan nyata dalam situasi sebagaimana adanya sampel penelitian.

\footnotetext{
${ }^{3}$ Iwan Ridwansyah, Penelitian Kuantitatif dan Kualitatif, dalamhttps://readwansyah.wordpress.com/20 10/10/09/penelitian-kuantitatif-dankualitatif/ (9 Oktober 2010) ${ }^{4}$ Ibid..,
} 
2. Manusia sebagai instrumen (informan), merupakan alat pengumpul data utama. ${ }^{5}$

Adapun yang menjadi objek penelitian ini adalah Penentuan Harga Dan Pembayaran Tempo Piutang DiLIK Magetan. Sedangkan Subjek dalam penelitian ini adalah pedagang-pedagang kulit yang ada Di LIK Magetan. Beberapa pedagang yang diteliti memiliki kriteria yang dalam penelitian sebagai berikut:

1. Orang orang muslim.

2. Pengusaha kulit yang bersedia diteliti.

3. Pedagang-pedagang kulit yang ada Di LIK Magetan

\section{PEMBAHASAN}

Pada awalnya kegiatan penyamakan kulit di Magetan masih tersebar di daerah-daerah dan belum terorganisir dengan baik. Oleh karena itu gubernur Jawa Timur pada saat itu meresmikan Lingkungan Industri Kulit (LIK) di Magetan. Sebagai wadah berkumpul para pengusaha penyamakan kulit di Magetan.

Dengan dibangunya Lingkungan Industri Kulit (LIK), secara berangsur-angsur para penyamak kulit yang tersebar di Magetan mulai memindahkan kegiatan usahanya ke dalam lingkungan LIK. Usaha pemerintah ini terbukti berhasil. Karena dengan dibangunya LIK maka akan mepermudah dala melakukan kegiatan pambinaan terhadap para perajin. Pemerintah mulai mendorong Industri Kulit Magetan dengan penerapan kegiatan industri berbasis teknologi. Sehingga Industri

${ }^{5}$ Ibid..,
Kulit Magetan bisa menghasilkan produk kulit berkualitas tinggi dan mampu bersaing di pasar nasional. ${ }^{6}$

Penentuan harga dan pembayaran tempo piutang pelanggan dalam perspektif etika bisnis syariah studi kasus di lingkungan industri kulit magetan membutuhkan pemahaman dalam melakukan akad transaksi jual beli, karena apabila kita memiliki pemahaman tentang apa yang akan kita lakukan berkaitan dengan usaha yang akan dikelola pasti akan lebih mudah dalam melakukan suatu usahanya, pemahaman itu tidak bisa diabaikan begitu saja oleh orang yang melakukan kegiatan dalam jual beli ataupun perusahaan atau lembaga yang bersangkutan.

a. Subjek 1

$\begin{array}{ll}\text { Nama } & : \text { PN } \\ \text { Umur } & : 50 \text { tahun }\end{array}$

Alamat : LIK jalan teuku umar Magetan

Pendidikan : SMP

Lama Usaha : 9 tahun

Jenis Usaha : Industri penyamakan kulit

Bapak PN kurang lebih sudah 9 tahunan menjalani bisnis di bidang Industri penyamakan kulit di LIK Magetan. Oleh karena itu, dalam melakukan bisnis pasti memerlukan pemahaman tentang akad dalam transaksi jual beli, pemahaman bapak PN mengenai akad dalam transaksi jual beli, beliau mengatakan : "Sing penting cocok rego yo tak kirim mas, nek masalah bayaran tempo sak

${ }^{6}$ Fery Dedi Supardi, Sejarah Industri

Kerajinan Kulit Magetan,

dalamhttps://www.sepatukulitmagetan.net/n ews/detail/sejarah-industri-kerajinan-kulitmagetan (24 February 2017). 
ulan." 7 (yang penting harganya cocok ya saya kirim mas, kalo pembayaran tempo satu bulan).

Melihat dari jawaban beliau di atas, dapat peneliti simpulkan bahwa beliau sudah memahami apa yang dimaksud dengan akad dalam transaksi jual beli itu. Berdasarkan hasil wawancara di atas diketahui bahwa bapak PN dalam pemahaman tentang akad transaksi jual beli ini sudah cukup memahami, seperti yang beliau katakan di atas.

b. Subjek 2

\begin{tabular}{ll} 
Nama & $:$ ML \\
Umur & $: 43$ tahun \\
Alamat & \multicolumn{1}{c}{$:$ LIK } \\
jalan teuku umar & \\
Pendidikan Terakhir & $:$ SMA \\
Lama Usaha & $: 4$ tahun \\
Jenis Usaha & $:$ Industri \\
penyamakan kulit &
\end{tabular}

Saudara ML ini sudah kurang lebih 4 tahunan menjalani bisnis di bidang Industri penyamakan kulit di LIK Magetan. Oleh karena itu, dalam melakukan bisnis pasti memerlukan pemahaman tentang akad dalam transaksi jual beli, oleh karena itu bagaimana pemahaman ML mengenai akad dalam transaksi jual beli, beliau mengatakan :Menurut ML akad dalam jual beli itu adalah transaksi antarapenjual dan pembeli dengan kerelaan hati dan pembayaran sistem satu nota.

Melihat dari jawaban beliau di atas, dapat peneliti simpulkan bahwa beliausudah memahami apa yang dimaksud dengan akad dalam transaksi jual beli itu.Berdasarkan hasil wawancara di atas diketahui bahwa ML dalampemahaman

${ }^{7}$ Parno, Wawancara, Magetan: 2 Agustus 2018. tentang akad dalam transaksi jual beli ini sudah cukup memahami,seperti yang beliau katakan di atas. ${ }^{8}$

c. Subjek 3

\begin{tabular}{ll} 
Nama & $:$ OP \\
Umur & $: 53$ tahun \\
Alamat & \multicolumn{1}{c}{$:$ LIK } \\
jalan teuku umar & \\
Pendidikan Terakhir & $:$ S1 \\
Lama Usaha & $: 7$ tahun \\
Jenis Usaha & $: \quad$ Industri \\
penyamakan kulit &
\end{tabular}

OP kurang lebih 7 tahunan menjalani bisnis di bidang Industri penyamakan kulit di LIK Magetan. Oleh karena itu, dalam melakukan bisnis pasti memerlukan pemahaman tentang akad dalam transaksi jual beli, oleh karena itu bagaimana pemahaman OP mengenai akad dalam transaksi jual beli,beliau mengatakan :Menurut OP akad dalam jual beli itu adalah proses transaksi antarapenjual dan pembeli seperti terjadinya negosiasi harga dan sistem pembayaran, itulahyang disebut akad dalam jual beli.

Melihat dari jawaban beliau di atas, dapat peneliti simpulkan bahwa beliausudah memahami apa yang dimaksud dengan akad dalam transaksi jual beli itu.Berdasarkan hasil wawancara di atas dapat diketahui bahwa OPdalam pemahaman tentang akad dalam transaksi jual beli ini sudah cukupmemahami, seperti yang beliau katakan di atas. ${ }^{9}$

d. Subjek 4

$\begin{array}{ll}\text { Nama } & : \text { SJ } \\ \text { Umur } & : 57 \text { tahun }\end{array}$

${ }^{8}$ Melin, Wawancara, Magetan: 2 Agustus 2018.

${ }^{9}$ Opik, Wawancara, Magetan: 2 Agustus 2018. 
Alamat : LIK

jalan teuku umar

Pendidikan Terakhir : SMA

Lama Usaha : 10 tahun

Jenis Usaha : : Industri

penyamakan kulit

SJ kurang lebih 10 tahunan menjalani bisnis di bidang Industri penyamakan kulit di LIK Magetan. Oleh karena itu, dalam melakukan bisnis pasti memerlukan pemahaman tentang akad dalam transaksi jual beli, oleh karena itu bagaimana pemahaman SJ mengenai akad dalam transaksi jual beli,beliau mengatakan :

Menurut SJ akad dalam jual beli itu adalah proses transaksi antarapenjual dan pembeli dengan keridoan, sedangkan untuk sistem pembayaran tunai setelah barang di kirim atau dengan pembayaran giro tempo satu bulan serta sesuai dengan kontrak kerjasama.Melihat dari jawaban beliau di atas, dapat peneliti simpulkan bahwa beliausudah memahami apa yang dimaksud dengan akad dalam transaksi jual beli itu.

Berdasarkan hasil wawancara di atas dapat diketahui bahwa SJdalam pemahaman tentang akad dalam transaksi jual beli ini sudah cukupmemahami, seperti yang beliau katakan di atas. ${ }^{10}$

e. Subjek 5

\begin{tabular}{ll} 
Nama & $:$ MJ \\
Umur & $:$ 40 tahun \\
Alamat & \multicolumn{1}{c}{$:$ LIK } \\
jalan teuku umar & \\
Pendidikan Terakhir & $:$ SMA \\
Lama Berdagang & $:$ 3 tahun
\end{tabular}

${ }^{10}$ Sujadi, Wawancara, Magetan: 3 Agustus 2018.
Jenis Usaha $\quad$ : $\quad$ Industri penyamakan kulit

Saudari MJ ini sudah kurang lebih 3 tahunan menjalani bisnis di bidang Industri penyamakan kulit di LIK Magetan. Oleh karena itu, dalam melakukan bisnis pasti memerlukan pemahaman tentang akad dalam transaksi jual beli, bagaimana pemahaman MJ mengenai akad dalam transaksi jual beli, beliau mengatakan :

Menurut MJ akad dalam jual beli itu adalah proses transaksi antara penjual dan pembeli sesuai persetujuan harga dan pembayaran, untuk pembayaran tunai harga lebih murah selisih dengan tempo serta cicilan.

Melihat dari jawaban beliau di atas, dapat peneliti simpulkan bahwa beliausudah memahami apa yang dimaksud dengan akad dalam transaksi jual beli itu.Berdasarkan hasil wawancara di atas dapat diketahui bahwa MJdalam pemahaman tentang akad dalam transaksi jual beli ini sudah cukupmemahami, seperti yang beliau katakan di atas. ${ }^{11}$

\section{KESIMPULAN}

Berdasarkan data hasil penelitian tentang penentuan harga dan pembayaran tempo piutang pelanggan dalam perspektif etika bisnis syariah studi kasus di lingkungan industri kulit magetan maka dapat penulis simpulkan bahwa:

Pemahaman pengusaha penyamak kulit di LIK magetan tentang akad dalam transaksi dari

\footnotetext{
${ }^{11}$ Mujiono, Wawancara, Magetan: 3 Agustus 2018.
} 
lima pedagang hanya empat pedagang yang benar-benar memahaminya. Satu pedagang lainnya kurang memahaminya. Dalam prakteknya, bahwa satu pedagang ini sudah menerapkan akad transaksi yang sesuai dengan tuntunan syariat, yaitu tidak boleh ada kesepakatan untuk menipu orang lain dan transaksi barang-barang yang diharamkan.

Menurut pengusaha penyamak kulit di LIK magetan akad itu sudah sah apabila si penjual sudah menerima pesanan barang melalui proses negosiasi dan siap mengirimkan kepada si pembeli lalu si pembeli membayar atas harga barang tersebut sesuai dengan sistem pembayaran yang telah disepakati, asalkan tidak ada paksaan dan dilakukan dengan rasa suka sama suka dari pihak penjual dan pembeli.

\section{DAFTAR PUSTAKA}

Wahbah az-Zuhaili. 2007. Fiqih Islam wa Adillatuhu. Depok: Gema Insani.

Abdul Ghofur. 2017. Pengantar Ekonomi Syariah. Depok: Rajagrafindo Persada.

Ismail Nawawi. 2012. Fikih Muamalah Klasik Dan

Kontemporer. Bogor: Ghalia Indonesia.

Musa Asy'arie. 2015. Filsafat Ekonomi Islam. Yogyakarta: Lembaga Studi Filsafat Islam LESFI.

Muhammad. 2017. Metodologi Penelitian Ekonomi Islam. Depok: Rajawali Press.

Adiwarman Azwar Karim. 2016. Sejarah Pemikiran Ekonomi Islam. Depok: Rajawali Press.
Oni Syahroni. 2017. Ushul Fikih Muamalah. Depok: Rajagrafindo Persada.

Adiwarman Azwar Karim, Oni Syahroni. 2015. Riba Gharar dan Kaidah-Kaidah Ekonomi Syariah. Jakarta: Rajagrafindo Persada.

Enang Hidayat. 2016. Transaksi Ekonomi Syariah. Bandung: Remaja Rosdakarya.

Sukron Kamil. 2016. Ekonomi Islam, Kelembagaan, dan Konteks Keindonesiaan. Depok: Rajagrafindo Persada.

Mustafa Edwin Nasution. 2017. Pengenalan Eklusif Ekonomi Islam. Depok: Kencana.

Eko Zulkifli. 2016. Etika Bisnis Syariah, dalam http://kumpulanmakalahekoszu lkiflilihawa.blogspot.com 18 Oktober

Munadi. 2014. Teori Kepemilikan dan Teori Akad. dalam https://www.facebook.com/fiq h.muamalah.com. 6 Januari.

Watim Maysaroh. 2014. Sistem Ekonomi Keadilan, Kejujuran dan Kesetaraan,

http://pecintaekonomiislam.blogspot. com. 6 April

Wardah Yuspin. 2015. Penerapan Prinsip Syariah Dalam Pelaksanaan Akad Murabahah, dalam https://www.researchgate.net 7 Mei

Bob Nelson. 2015. Pengertian Sumber Daya Manusia dan Manajemen Sumber Daya Manusia, dalam http://ciputrauceo.net. 29 Oktober 
Iwan Ridwansyah. 2010. Penelitian Kuantitatif dan Kualitatif, dalam

https://readwansyah.wordpress.com.

9 Oktober

Tiara. 2009. Etika Pelayanan Islami, dalam

http://tiaraekonomi.blogspot.co m. 14 Juli

Taufiq Jibu. 2013. Kepuasan dan Loyalitas Konsumen, dalam http://www.taufiqjibu.com. 31 Maret 
